\title{
THE MANY USES OF FORGERIES: THE CASE OF DOUVILLE'S VOYAGE AU CONGO
}

\author{
JAN VANSINA \\ UNIVERSITY OF WISCONSIN-MADISON
}

A forged travel account reminds me of a raffia palm in central Africa, because there is a use for every part of such a palm: the wine (sap), the nuts (edible), the raffia (for textiles), the other leaves (for roofcovering), the branches (for furniture), its pith (for making various articles), and lastly the grubs inside the pith (also edible). Nothing is wasted. In the same way a forged travel account can be deconstructed until all its parts down to the very last sentence or proper name can be used as evidence for one or another kind of history. The considerable interest fraudulent travel accounts can have for the historian of Africa is usually far underrated because once they are exposed as forgeries they tend to be summarily dismissed and henceforth to be avoided like the plague. At most, it is conceded that sometimes part of a forged account rests on the author's observations and experiences at the time and in the place where his (the known forgers seem to have been all male) narrative placed them and may therefore actually be genuine. ${ }^{1}$

The usefulness of forgeries as evidence goes well beyond this, however, and rests on two arguments. First, a narrative forgery is never totally the product of a person's imagination, if only because it strives to achieve the verisimilitude required to be passed off as genuine. A good part of any such forgery must therefore rest on valid observations made by someone, somewhere. If one can discover from where and

${ }^{1}$ For the treatment of comparable cases see Marion Johnson "News From Nowhere": Duncan and "Adofoodia," HA 1(1974), 55-66 and Mike Parker Pearson, "Reassessing Robert Drury's Journal as a Historical Source for Southern Madagascar," HA 23(1996), 233-56. For an historical critique about travels in general see Percy G. Adams, Travelers and Travel Liars 1660-1800 (Berkeley, 1962) and for Africa the relevant contributions in Beatrix Heintze and Adam Jones, eds. "European Sources for Sub-Saharan Africa before 1900:Use and Abuse," Paideuma 33(1987), esp. 179-206, 391-406.

History in Africa 31 (2004), 369-387 
when such elements stem, they add new evidence to the record about that where and when. Secondly, the very choice of topics and themes raised in a forgery is historical evidence in its own right, for it tells us much about the expectations of both the social milieu in which the work was written and its intended audience at the time (not always the same social aggregates). To develop and illustrate these points, there may well be no better instance than the notorious book whose unmasking raised a great geographic furor in the earlier nineteenth centurythe notorious Douville forgery.

On 30 March 1832 the Sociéte de Géographie de Paris awarded its prestigious golden medal to Jean-Baptiste Douville "for his travels in the Congo and in Equinoctial Africa," and the Royal Geographical Society of London made him an Honorary Member. The remarkable discoveries related in that book were made during two separate and consecutive voyages. The first of these occurred mostly, although not completely, within the ambit of the Portuguese colony, while the second, more sensational, voyage struck deep into the interior to the north and east of that colony. The reaction to Douville's fame today may well be: Who? Never heard this name at all! How is it possible for such an illustrious explorer to have become so thoroughly forgotten?

The short answer is because, barely four months after the award was made, came a painful discovery. By August 1832 Douville was being loudly denounced in London, and by November in Paris as an adventurer whose Voyage au Congo et dans l'intérieur de l'Afrique équinoxiale fait dans les années 1828,1829 , et 1830 was not a major landmark in geographical exploration but a forgery which had duped the members of the foremost learned societies in France and to a lesser degree in England. An anonymous article in the Foreign Service Quarterly first set the ball rolling. ${ }^{2}$ Later the traveler and publicist Theodore Lacordaire, writing in the prestigious Revue des deux mondes, concurred and extended the charges. ${ }^{3}$ These charges provoked a

2W. D.Cooley], “Article VIII," Foreign Quarterly Review 10(19 August 1832) 163206, and rebuttal of Douville's defense, ibid., 541-46. For Cooley see Roy Bridges, "W.D. Cooley, the RGS and African Geography in the Nineteenth Century," Geographical Journal 142(1976), 274-86.

${ }^{3}$ Théodore Lacordaire "Revue de Voyages," Reune des Deux Mondes 8(November 1832) 245-62, and rebuttal of a second defense by Douville, ibid., 495-500. The publication was scheduled for 15 October, but was delayed to November. Since the journal had actually published a large extract of Douville's book, preceded by a very laudatory introduction, its editor must have found the evidence convincing enough for a total U-turn. 
storm of controversy between the faithful and the unbelievers, in the name of the reputation and the "honor" of famous geographers and their foremost societies. ${ }^{4}$ Douville's rebuttals were unconvincing and the evidence adduced, especially in Cooley's article, was so overwhelming that the doubters soon won. ${ }^{5}$ By the spring of 1833 it was generally accepted that, while Douville had actually been in Angola, he had neither traveled outside its limits nor made the discoveries for which he had been honored. The whole episode was so humiliating to the savants and their learned societies that they could only hasten to forget the whole affair and, above all, never reopen such painful wounds by reminding others of the very existence of the now damned work.

Yet not everyone dismissed his book out of hand as worthless. No less a personage than Brigadier da Cunha Matos, in his work of 1836, appreciated Douville: ". . . for despite the scepticism of many about his travels to Congo and in equinoxial Africa, I know that he owned many excellent data with which he arranged a great part of his work." 6 But he knew also that Douville hid facts known all over the colony, that he made errors through ill information and anti-Portuguese bias-one of the big blunders being his description of the colanut-that he sometimes plagiarized, and sometimes "lacked in truth by being not quite honest."7 Elsewhere he sometimes approved of Douville and sometimes criticized him, but only about places within the limits of Portuguese territories. Thus we are told that "all that $\mathrm{M}$. Douville says about the customs of the rulers and their people in the bush is quite true," but also that " all this [an embassy from the Rund emperor to Luanda in 1807] was hidden by the French traveler M. Douville, who in his História do Congo [sic] stepped out of line by keeping facts secret which are known even to the most insignificant persons in the colony," while elsewhere

4he debate involved all the most influential French newspapers and periodicals of the moment.

${ }^{5}$ Although no one knew much about the regions beyond the colony of Angola at the time, Cooley exposed the forgery by showing inconsistencies, improbabilities (e.g., too fast a rate of travel), impossibilities (some astronomical observations, orography, river flow etc.) and arguments of silence. The most telling evidence stemmed from his exposure of alternative chronologies in the text and in the astronomical tables and of a systematic error in the cartographic (and hence astronomical) data to extend the travels as far as the equator and halfway across Africa. He made it clear that Douville was ignorant of physical geography. Lacordaire pointed out that he was just as incompetent in the natural sciences.

${ }^{6}$ R.J. da Cunha Matos, 370(Rio de Janeiro, 1963), 314. Cunha Matos arrived first in Angola in 1797, ibid., 305-06, and spent 19 years in Africa (ibid., 331), for the most part in São Tomé. Internal evidence (ibid., 21) shows that his book manuscript was completed in 1836.

${ }^{7}$ Ibid., 309, 312, 336 and 324. 
he spoke of Douville's ". . . interesting travels in Congo and equinoctial Africa, a work which I analyzed to show the innumerable errors committed by its author, because he was ill informed, or because he wanted to disparage the Portuguese government." 8 Nevertheless, Douville made quite an impression on him since he often cited or copied him.'

Douville's work had been composed in the style of the grand geographic tradition modeled after the example of Alexander von Humboldt. ${ }^{10}$ Its contents laced the description of his travels and the description of landscapes with observations related to geology, climate, metereology, natural history, and a good deal of ethnography. Matos focused on parts of the travel and on the ethnography and apparently conceded all the rest as practically valueless.

As more new information became available about Angola during the 1840s, Douville was soon forgotten, at least until Anne Stamm made a misguided attempt to rehabilitate his work despite the farrago of boasts of having traveled around lake Malawi, to have reached the Equator at $30^{\circ}$ East (that is, near the northern shores of Lake Edward!), and then to have reached a point not far south from the Mountains of the Moon and a mighty river which came from lake Tchad and ran to Egypt. ${ }^{11}$ Stamm convinced herself that he had really traveled wherever he claimed, and that his observations-and even his numbers-were correct, although his cartography was just a little defective. For her nothing in his work was fictional and she set out to prove this. ${ }^{12} \mathrm{Her}$ article attracted a brief but telling rebuttal by Joseph Miller, who drew atten-

${ }^{8}$ Ibid., successive quotes $337,309,312$

${ }^{9}$ Ibid., 306-07, 317, 318, 319, 320, 322, 324, 326, 328, 330, 333, 336-38, and 34344. for other citations. For unacknowledged use of data from Douville see below.

${ }^{10}$ And Humboldt seems to have been his explicit model according to Lacordaire, "Revue," 252-53. Indeed the very title of his book "dans l'intérieur de l'Afrique équinoxiale" recalls the title of Humboldt's first volume Voyage aux régions équinoxiales du nouvaux continent (Paris, 1805) in his thirty-volume set Voyage de Humboldt et de Bonpland (Paris, 1805-34). In Douville's time Humboldt was still the great hero of the geographical sciences in Paris, for it was the center where the scientific results gathered on his travels in South America (1799-1804) were being published.

11 Jean-Baptiste Douville, "Aperçu de l'itinéraire de M.Douville dans le centre de l'Afrique, fait dans les années 1828, 1829 et 1830," Bulletin de la Société de Géographie de Paris 16(1831), 17 (Malawi), 20 (Tchad, Mountains of the Moon, and Nile); idem., Voyage 3:123 (the Nourihe flows to the northeast and the etymology of its name is Arabic) 129, abandoned intention to travel to Egypt). Still, he prudently withdrew his claim about Lake Malawi between June and November 1831, for it does not appear in his "Esquisse des peuples nègres au sud de l' Equateur," Bulletin de la Société de Géographie 16(1831), 200-01.

${ }^{12}$ Anne Stamm, " Jean-Baptiste Douville: Voyage au Congo (1827-1830)," Cahiers d'Etudes Africaines 37(1970), 5-39. 
tion to three letters proving that Douville was in the presidio of Pungo Andongo by 28 April 1829 , and was still stranded there by 2 October of the same year, when, according to his book, he supposedly was traveling outside the colony and much further into the interior. ${ }^{13}$ Douville was not rehabilitated, although scholars still accept that he had indeed traveled within the colony to its furthest extent to the east (Pungo Andongo), as the letters cited by Miller showed. Miller concluded that the information in Douville's work "rings fairly true" for Portuguese activities but "totally false" for ethnographic data on Africans, at least for the regions of Kasanje, Cokwe, and Lunda, with which Miller was most familiar.

\section{III}

When I turned in the 1990 s to a study of the social history of Ambaca, I found that most of Douville's descriptions of local sociopolitical conditions and practices for the lands within the territory could be relied upon and were quite informative. ${ }^{14}$ That prompted this attempt to delineate what is reliable evidence in Douville's travels and what it is evidence for. To do this one must first separate the fraudulent parts in Douville's account from the others. He claimed to have made two separate circuits, the first one all around, but within, the colony from Luanda to Luanda, the second one from Ambriz, just to the north of the colony, around its northern and eastern borders as far as the capital of the Mwant Yav and even beyond before returning to Ambriz. These circuits were well-known at the time in Luanda because together they constituted all the routes along which slaves arrived in the city or in the port of Ambriz to its north. ${ }^{15}$

A detailed examination of the itineraries constituting Douville's first trip shows that they correspond first to the much-traveled northern highway from Luanda to Golungo Alto, Ambaca, and Pungo Andongo, and then back from there to Luanda along portions of the southern route. A first-rate source, consisting in a bundle of reports written between 1846 and 1848 by named government officials, most of whom were local Luso-Africans, allows us to cross-check his itineraries in considerable detail. ${ }^{16}$ These reports confirm the way-stations along

${ }^{13}$ Joseph C. Miller, "A Note on Jean-Baptiste Douville," Cahiers d'Etudes Africaines 49 (1973), 150-53.

${ }_{14}^{14}$ Jan Vansina, "Ambaca Society and the Slave Trade ca. 1760-1845," forthcoming. ${ }^{15}$ Joseph C. Miller, Way of Death (Madison 1988). See maps, pages 24, 29, 36, 148, 210, 211, 216, 230-31, 258.

${ }^{16}$ They are bundled together and published under the title "Noticias de alguns dos districtos de que se compōe est provincia," Annaes do conselbo ultramarino. Parte näo official, II(1859), 81-82; (1860), 83-93, 123-57. Other itineraries and travel descriptions from the 1830 s and early 1840 s complement this body of data. 
Douville's route and the existence of nearly all the chiefs and chiefdoms he mentioned and whom he lists in the correct order of travel along that route. His excursion into the Regency of the Dembos, however, was not as extensive as he claimed. He certainly went from Bango Aquitamba, where there used to be a Carmelite mission and to the Lombige in search of the goldfields there, and he seems to have reached Cassatola, the seat of the Regency.

But the itinerary of his visits to the main lords of the area that follows is too erratic to carry conviction. He may well have gathered most of the information about them from the Regent in Cassatola and he says himself that he met Ngombe Amuquiama after his return to Luanda, when that chief was languishing in jail there. ${ }^{17}$ The smoking gun in this matter is that in his first account after his return to Paris he boasted of having gone even further north-all around the district of Encoge, where he discovered malachite mines and showed this itinerary on his map, but in his book he quietly dropped this claim altogether. ${ }^{18}$ He actually seems to have gone from Cassatola to Golungo Alto and then back on the main highway.

More doubts are raised about his travels from Pungo Andongo to Luanda. Supposedly he first went south of the Cuanza to explore the Benguela highlands between Benguela itself and Bihe before returning to a point not far from Pungo Andongo, and from there to Luanda by the then usual southern route, with an excursion to mountains of salt, which he placed in Kisama. In fact he returned directly to the capital along the southern route, without any forays south of the Cuanza river. Again he cited way-stations and chiefs along the direct southern route, and they are all in correct order, but much of what he had to say about the lands to the south of the Cuanza is plainly nonsense. To list only the most blatant errors: (i) he claimed to have climbed a very high active volcano called Zambi south of the Cuanza, but there are no volcanoes there; (ii) he saw mountains of rocksalt where none exist; (iii) he could not have gone from Bailundo to Benguela in the time alloted for this; (iv) he fatally mislocated a series of way-stations on his itinerary

\footnotetext{
${ }^{17}$ Douville, Voyage 1:63, stated that the governor let him go into the interior in order to attempt to find the goldfields which had been known for a long time to exist somewhere in the Lombige basin and that he found them just as another person sent by the governor with the same mission arrived nearby (ibid., 299-300). Whether Douville or the unnamed "other" did, the regime of this governor is credited with the export to Lisbon of some gold from these gold fields (José Joaquim Lopes de Lima, Ensaios, III De Angola e Benguela [Lisbon, 1846], 22, 128-29). On Ngombe Amuquiama, Douville's "Gomé Amuquiama," see Voyage I:256-74 (including the later visit in jail).

18 Douville, "Aperçu," 10-11. The malachite mines are the mines at Bembe, north of the district of Encoge.
} 
to Bihe; ( $v$ ) he did not mention the route from Bihe eastwards towards the Lwena valley which was then the most profitable for the slave trade to Benguela, nor were the ethnic names such as Cokwe and Lwena associated with it known to him. ${ }^{19}$

Douville's second voyage supposedly began in Ambriz on the coast north of Luanda. From there he turned around the colony to reach the great market of Cassange near the Kwango river to its east. He crossed that river upstream from Cassange and traveled to the capital of the Mwant Yav and even somewhat beyond. From that capital he then returned to Ambriz along a northwestern route, crossing the Kwango well downstream from Cassange and visiting the seat of the main chief of the Soso along the way. While all these routes did exist at the time they were not located where Douville assigned them, nor did he travel along them. The whole second voyage is a sham. None of the majestic mountains, great lakes, deserts, rivers, gold mines, and lead deposits that decorate his account actually exist, while on the other hand the text is strangely silent about remarkable features (such as the Stanley Pool and the Falls of the Congo river near Kinshasa) that could be admired along his supposed itinerary. All that a generous critic could concede about this second voyage is that, just maybe, the ship on which he returned to Bahia, made a short stop at Ambriz and that Douville visited the town on that occasion. ${ }^{20}$

The astronomical and meteorological tables in the appendix are sheer inventions and are in any case totally useless today. With the exception of figures for Luanda and Benguela, the population statistics that follow are also fabricated, although they are patterned after the statistics kept by the Portuguese about their cities and presidios. The vocabularies with which the work concludes again are sheer fiction, with the exception of Kimbundu and some entries for Kikongo. Douville may have gathered some Kimbundu and Kikongo words himself, but he copied most of them from the Cannecatim dictionaries. ${ }^{21}$

${ }^{19}$ (i) Douville, Voyage 2:225-33, (ii) ibid., 254-55, 15-16; (iii) conceded by Stamm, "Jean-Baptiste Douville," 15; (iv) Douville, Voyage, 15-16, attributing this inversion to clerical error during the write-up of the text; v) argument of silence, but the route had been opened in the 1790 s and it was to be the one by which Graça (1846) reached the Mwant Yav.

${ }^{20}$ Stamm, "Jean-Baptiste Douville," does not contain a single credible argument or explanation against the view that the account is a forgery, whereas that view is actually strongly supported by some of her observations, and above all by the discrepancies between Douville's preliminary lecture in 1831 .

${ }^{21}$ Bernardo Maria de Cannecatim, Diccionario da lingua bunda ou Angolense (Lisbon, 1804); idem., Collecção de observações grammaticaes sobre a lingua Bunda ou Angolense e diccionario abbreviado da lingua congueza (Lisbon, 1805). Douville's Mogialoua vocabulary was probably fabricated by slightly altering Kimbundu or Kikongo forms. The Bomba set of three dialects betrays its fake char- 
It stands to reason that, because Douville invented part of the first and the whole of his second voyage out of thin air, he also had to create a chronology that would leave room for his fictitous expeditions, and it has been evident to his critics from the outset that he had tampered with his dating. ${ }^{22}$ The chronology of his first and only voyage must therefore be established by other means. We know that he left Brazil in March 1828 at the very earliest, although the date of his actual departure remains to be found. ${ }^{23}$ The next relevant document apparently was a passport delivered in Luanda on 16 February 1829, which Douville offered in his defense and whose authenticity was not questioned. He claimed that this was delivered on the eve of his second trip into the interior. My suspicion is that it was delivered on the eve of his first trip. 24

Letters dated to 28 April, 18 July, and 2 October 1829 establish that Douville was marooned in Pungo Andongo for lack of porters. He seems to have arrived there in April, while in October orders were given for his immediate expulsion. 25 "Immediate" was of course relative since he still had first to return to Luanda. We do not know exactly when he sailed from Angola to Bahia, only that he arrived in Rio de Janeiro from Bahia before 1 June 1830, when he wrote from there to the Société de Géographie de Paris. Given the most common duration for the crossing and for the trip Bahia-Rio, that means that he must have left Luanda sometime in March $1830 .{ }^{26}$ The available evidence is therefore sufficient to state that Douville's voyage in the interior of Angola occurred in 1829.27 That is a year later than he claimed, since

acter by the prominence given to suffixes rather than prefixes (clearly Douville did not fully understand how prefixes work), by infantile devices such as endings in $-z$, or $-\mathrm{x}$, or the use of double ff-, by the utterly unrealistic forms for his numerals one to five and the use of a system on base-five rather than the decimal system.

22 [Cooley], "Article VIII," 191-94; Miller "Note," 151-52.

${ }^{23}$ Lacordaire, "Revue," 257; idem., "Douville. Pièces justificatives," 500, claimed to have seen him in Rio in March 1828. Consultation of the registers of arrival and departure from Rio de Janeiro may well provide the dates at which he really left and returned to the city.

${ }^{24}$ Lacordaire, "Douville. Pièces justificatives," 496- 98. Note that it could not be a passport delivered for his second trip since he (Voyage 2:268-69) said that he hid his plans for this voyage from the authorities. In his defense Douville also submitted two letters from the Governor-General addressed to him in Golungo Alto and dated 1 March and 28 April 1828, but the dates were added in another hand than the body of the text, which renders them suspicious.

25 Miller, "Note," 151-52.

${ }^{26}$ Stamm, "Jean-Baptiste Douville", 36. Note that he himself (Douville, Voyage, 3:225) claimed to have reached Rio only on 12 July 12 . A crossing usually took between one and two months and the Bahia-Rio trip took twelve days' of travel plus one of rest in Bahia (ibid.).

27 Indeed, Graziano Saccardo, Congo e Angola (3 vols.: Rome, 1982-83), 2:504, $521,3: 298$, dates his visit to the convent on the lower Bengo at the outset of his voyage to 1829 as a fact without further comment. 
according to his tables he left Luanda 25 January 1828 and and was back on 1 January $1829 .{ }^{28}$ Thus, instead of a voyage lasting "thirty months" (15 December 1827-30 June 1830), the real trip lasted only about half that time.

\section{IV}

How then can historians exploit this partly genuine/partly false source? The first consequence of the conclusions we just reached, is that a sizable portion (about $40 \%$ ) of Douville's text actually deals with his real travels in Angola. ${ }^{29}$ However, even this portion is not completely reliable. To begin with, most of his observations relating to the physical geography and natural history of the regions he visited are clearly fake and in any case superseded by modern observations. Secondly, as did most other travelers at that time, he also used a literary style replete with rhetorical devices, especially conversations and "privileged information." Lastly, he added a number of sensational or shocking and mostly fictional episodes-that is, sensational in France or Britain around 1830-concerning religious beliefs and rituals involving priests and magicians, as well as the conduct of women. ${ }^{30}$ On the other hand, his information about the local colonial administration and about Ambundu society seems to be reliable enough, even though he rarely tells us whether his information stemmed from what he saw himself, from what he was told, or from what he had read in the various archives kept in Luanda, Benguela, and the local administrative headquarters. Still, it is remarkable that his data about Ambundu society are wholly consistent with the known later evidence. ${ }^{31}$

The question now becomes whether even the genuine portions of his account are at all useful. Is not nearly all the evidence about the colonial situation available in hitherto unpublished archives? And while his data about Ambundu society may be so consistent with later evidence of much better quality, why do we need to use them at all? The answer is no to both questions. We know that much of the local archival materials have been lost, and that most of the scandals Douville exposed

${ }^{28}$ Douville, Voyage 3:tables, 252, 254. But according to the travel account (ibid., 1:64), he left Luanda on 6 February 61828 . Note, however, that while he falsified the year he tampered only slightly with the with the months of his dates because he felt the need to maintain the correct wet and dry seasons.

${ }^{29}$ These include all of volume 1 ( 325 pages) and pp. 234-54, 256-77 of volume 2, for a total of 366 pages out of 926 , or $39.5 \%$ of the whole, excluding the appendices.

${ }^{30}$ Quite conveniently for us, Douville, "Esquisse," 201-04, summarized in a short paper all the main stereotypes of his work.

31 Vansina, "Ambaca Society." 
would not have been reported in any case, or that, if they were, they would be cast in a completely different light. ${ }^{32}$ As to the ethnographic data it appears that because Douville was writing for a French public his account is more detailed and often more explicit than later authors who, being either Luso-Americans or old hands in the colony, did not see the necessity for adding much detail. Last but not least, Douville' evidence is valuable in itself because it dates to 1829 , that is, at the height of the slave trade, whereas the reports of $1846-48$ date to just after its abolition. Since the twenty intervening years saw such momentous changes, Douville's testimony on many a point remains actually irreplaceable and invaluable. ${ }^{33}$

\section{V}

Nevertheless, most of Douville's text is a forgery. Is there then no fodder for the donkey in this large mass of pages at all? There is, but in order to find it one must first learn why, when, and how Douville constructed his forgery. Lacordaire claimed that Douville wanted to be another Humboldt, long before he ever reached Angola, and certainly his Voyage seems in general to be modeled after that illustrious example; its title certainly is. It is also evident that, at the latest from the date of his return to Rio if not before, Douville coveted the medal of the Société de Géographie, with the prestige that accompanied this award. The inspiration to create a complete forgery, rather than one limited to the data on physical geography, may well have come to him during the time when he was immobilized at Pungo Andongo between April through October of 1829. A first draft was composed in 1830-31, when he was still in Rio, but the final text was obviously written in France after his return there in June of 1831, and even after he delivered the lectures to the Sociéte that were published in its Bulletin of July and December $1831 .{ }^{34}$ As the fictitious itinerary to Encoge shows, he

${ }^{32}$ About the loss of archives see, for instance, Manoel Alves de Castro Francina, "Itinerario de ume jornada de Loanda ao Districto de Ambaca, na provincia de Angola," Annaes do conselho ultramarino. Parte não official, 1a serie 1854-1858, 1854, 7-8. Some losses ascertained in Ambaca in 1846 were wilful and exonerated certain local officials. Francina, "Viagem a Cazengo pelo Quanza e regresso por terra" in the same year of Annaes, 456, 459, 461 reports for 1847 that the archive at Muxima was not in order and contained no correspondence earlier than 1838 , that the one of Massangano was not in order and contained only a portion of the expected correspondence, and that very little was written down at all in Cazengo. The lack of records in Lisbon and in ecclesiastical archives led Saccardo (note 27 above) to cite Douville about the state of the Bengo mission in 1829.

${ }^{33}$ Thus João Guilherme Pereira Barbosa, “ Cazengo," Annaes (May 1858), 471- 72, dated to 20 June 1847 , describes how dramatically the situation of the inhabitants there had changed in the preceding fourteen years.

${ }^{34}$ Douville, "Aperçu" and, idem., "Esquisse." Thus he omitted a planned travel account to Encoge after the first lecture was given. 
clearly drew his maps and his tables first before he completed his final text. During his stay in Paris, Adrien-Hubert Brué, who constructed his final map, and one or more astronomers, as well as other scholarsprobably inadvertently-helped him to create his forgery simply by the questions they asked, and the books they referred to-a process to which Douville actually alludes himself in his work. ${ }^{35}$

Douville may well have begun by interpolating the excursion to the Benguela highlands to his first travels because he could easily fit this into his chronology by attributing the time he spent in fact waiting at Pungo Andongo to the execution of this trip. But once he created a wholly fictional second voyage, he also needed to invent a complete new overall framework of itineraries for it. He chose to construct a route for this voyage that followed along the itineraries of existing slave trading routes between Ambriz and the capital of the Mwant Yav in the far interior, no doubt because they avoided the Portuguese colony and so allowed him both to boast of astonishing revelations, yet avoid exposure.

Still, there was one further requirement. In order to gain the coveted medal he had to reach very far into the interior, at least as far as the equator northwards and eastwards at least into what was then considered eastern Africa. ${ }^{36} \mathrm{He}$ duly managed to provide stretched longitudes and latitudes both on the partial maps he gave to Briue and even more in his text. ${ }^{37}$ Then he provided a final touch as a crowning glory to the whole voyage, an allusion to the discovery of the upper Nile. For that purpose he used the name of a ruler called Bomba, a well-known name in Luanda because chief Bomba, who ruled in Songo country well to the southeast of Cassange, had also sent an envoy to Luanda in 1807 when those sent by the Mwant Yaav to the Angolan capital passed through his residence. ${ }^{38}$ But Douville transposed his realm beyond the

${ }^{35}$ Douville, Voyage 2:374. Obviously all of pages 373-77 were added shortly to an older text before publication. The omission of any reference in the text to the copper mines at Bembe north of Encoge, of lake Chad, and of lake Malawi was probably the result of warnings given by friendly advisors. The location of at least these places was already well-known in Europe at that time and they did not fit in easily with Douville's travels.

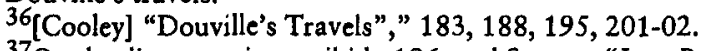

${ }^{37}$ On the discrepancies see ibid., 196, and Stamm, "Jean-Baptiste Douville," 11. The discrepancy indicates that he finalized his text after his maps had been handed to the cartographer while the reverse would imply that Brué was a party to the deception. ${ }^{38}$ Douville knew about Bomba and the embassy from the Mwant Yav from the account of João Carlos Feo Cardoso de Castello Branco e Torres, Memórias contendo a biographia do vice-almirante Luis da Motta Feo eTorres, a História dos governadores e capitaes generaes de Angola desde 1575 até 1825, e a Descripção geographica e politica dos Reinos de Angola e Benguella (Paris, 1825), 300-01, which he cites in Voyage 1:41-42. For Bomba and "Giringbomba" see also Matos, Compendio, 306-08. 
equator by conflating his name with that of the "Giringbomba," who appears the furthest north and northeast on the map elaborated in $1666 / 67$ by Dapper. ${ }^{39} \mathrm{He}$ thus turned Bomba into the terminus of knowledge about innermost Africa and the start of the road to Egypt. ${ }^{40}$

Once the overall conception and the main framework of the fraudulent parts of the were clear, it remained only to invent the contents of the narrative. In order to do this Douville used a variety of different inputs that can be traced in his text. They are maps and documents, oral accounts given to him by expert informants (that is, persons who had themselves seen and experienced what they told him), indirect hearsay, the transposition of his own observations in the parts where he actually had traveled to different locations, and inspiration drawn from publications about other parts of the world, such as other travel accounts and perhaps even works of fiction. Most of these inputs can be identified, which allows one to unravel the narrative, to determine the sources of particular assertions, and to identify some credible assertions that are not (yet?) known from elsewhere, or known only from a later date. ${ }^{41}$ Let us then briefly survey the different kinds of inputs.

\section{VI}

The most obvious existing written materials Douville used are maps. Among these the map of Angola dated to 1790 by L.C.C. Pinheiro Furtado which gave him a general overview for the whole area, west of the Kwango, is the most obvious. ${ }^{42}$ Douville clearly used it for the story of his travels to the Benguela highlands and to Cassange and his return

${ }^{39}$ Dapper's 1667 map (Dapper, Naukeurige Beschryvinge der afrikaensche Gewesten (Amsterdam, 1668) has Giribuma. Cf. Vossius, Tabula (Amsterdam, 1666) has Giringbomba sev. Gingirbomba north of the Equator; E. Sulzmann, "Orale Tradition und Chronologie: Der Fall Baboma-Bolia (Nordwest Zaire)" in C. FaïkNzuji Madima and Erika Sulzmann, eds. Mélanges de culture et de linguistiques africaines (Berlin, 1983), 526-28. Douville may have heard about or seen a copy of Dapper's map in Rio because "Bomba" was already present in the lecture he gave to the Sociéte barely a month after his return to France.

${ }^{40}$ For Bomba in Douville see Voyage 3:111, 122-23, (Kilihé, Nourihé, named Nourihe because of its scintillating sand and the "sparkling stones which fill its bed"). Cf. Nu:ri, "luminous" in Arabic), 126, and 129 ("my health made me abandon the project to return to Europe via Egypt").

${ }^{41}$ For instance the supposed war between Bailundo and Bihé in 1826 (Voyage, 2:117-18); the first or an early mention of the Muchingi or Shinje people (ibid., 324 and map); the "wandering people" north of Bihé (ibid., 170-71); the (probably erroneous) story about Bihé's origin from Humé (ibid., 153-56). Later mentions which date to the 1880 s may well have been plagiarized from Douville.

${ }^{42}$ L.C.C. Pinheiro Furtado, Carte geographica da Costa ocidental da Africa . . . Desenhada. . . . em 1790, published in Torres, Memórias. Douville, Voyage 1:42-43, cited this work. 
from Dembo Hialala of the Soso to Ambriz. He also used Dapper's map and he may have used maps derived from Dapper for portions located north of the Furtado map near the present Malebo (Stanley) pool, such as one of the well-known maps of d'Anville. ${ }^{43} \mathrm{He}$ knew about some of the major late sixteenth- and seventeenth-century printed works about Kongo and Angola, but does not seem to have made much use of them, and he demonstrably mined the work of Torres for a great deal of his information. ${ }^{44} \mathrm{He}$ used some administrative and ecclesiastical archival material in Benguela and Luanda at least, and perhaps also some documents in the archives of the local administrative headquarters. ${ }^{45}$

Douville's expert informants seem to have been administrators and traders, most of whom were Luso-Africans, and Ambundu chiefs or notables. ${ }^{46}$ However, what they told him is often not reliable because exaggerations and hearsay certainly crept in their accounts. Moreover, they clearly hid their knowledge about itineraries eastwards from the Kwango and north of the colony from him because these were trade secrets, and he does not seem to have questioned slaves from the far interior to compensate for this. Most of what Douville had to say about conditions and incidents on the Benguela highlands and in Cassange actually stems from traders, as do most of his stories about the adventures of caravans, even though he claimed all the credit for himself. ${ }^{47}$ One should therefore not summarily dismiss material of this kind in these sections but closely question its reliability.

${ }^{43}$ For instance, J.B. D'Anville, Carte particulière du royaume du Congo (Paris, 1731), reproduced in W.G.L. Randles, L'ancien royaume du Congo (Paris, 1968), 108-09.

${ }^{44}$ Douville, Voyage 1:42 for Torres (cited as Féo Cardozo). He cites those (ibid., 2:374) of "Lopez" [Pigafetta and Lopez], Battel, Merolla, and Cavazzi as well as "others" but he does not seem to have been very familiar with any of them. I suspect that the Parisian and London savants drew his attention to them.

45 E.g. Douville, Voyage $1: 16,27,31,41,302 ; 3: 260$. All administrative headquarters held some archives, mostly correspondence, and Douville may have been given access to a few of these papers.

${ }^{46} \mathrm{He}$ often quoted administrators and local dignitaries, but not traders in the genuine part of his travels. When it comes to the imagined parts of his travels (with the exception of the Dembos) all the information is supposedly given by chiefs or dignitaries, but actually it is of his own invention, or in some instances relating to Cassange and Benguela, stems from slave traders, although he is quite careful never to cite such sources.

47 I suspect that Douville obtained most of his information about the highlands and Cassange from interlocutors in Pungo Andongo who were directly involved in the trade to these destinations, as well as in Luanda. He does not seem to have talked much to traders in Ambaca, for he has little to say about Matamba, Bondo, or Holo, and most of what he does say is nonsense. Yet traders in Ambaca were very well acquainted with these regions, which they constantly visited. 
The voyage demonstrably includes various items of patently reliable information about the Benguela highlands such as the 1826 war of Bailundo, the description of the market at Bihé and its early history, and the capture of a Portuguese cannon in Haco. ${ }^{48}$ Hence quite a bit more plausible evidence of this sort can be found in the text relating to these highlands, once its narrative is analyzed in more detail. ${ }^{49}$ Some reliable information of this sort, which must stem from traders, also occurs in the narrative about Cassange-e.g., the ethnic name "Muchingi" [Shinji] and some data concerning the market in Cassange-but there are far fewer of these than in the portion dealing with Benguella. Indeed the Cassange section actually also contains parts that notwithstanding a look of plausibility are apparently completely invented. ${ }^{50}$ Elsewhere the fictional portions of the travels lack any evidence obtained from knowledgeable traders, with the exception of the texts about the inquita initiation among the Soso, about the trade terminus at the Soso chief Ambage's residence, and about the existence of a confederation among Soso chiefs. ${ }^{51}$

The best example of general hearsay or rumor in Douville's account is the story about lake "Couffoua," the "lake of death." He supposedly first heard about it at Cassange from African traders who supposedly had been far beyond the Kwango river. In fact he certainly heard about it in Pungo a Ndongo, or perhaps Ambaca. This lake is supposedly so large that birds could not cross it and drowned in their attempts to do so. This stereotype was already known at Cassange in 1755 and the story was still told about a lake in Kasai in the $1950 \mathrm{~s} .{ }^{52}$ Douville's stories about cannibalism and human sacrifice at Cassange, or about the hollow baobab used as a jail, are other easily detected clichés of this sort. ${ }^{53}$ These are easily detected, not just because they are self-con-

${ }^{48}$ Douville, Voyage 2:17-18 (Bailundo war 1826), 2:118-19 (panyaring in Bailundo), 2:142-47 (Bihe market), 2:153-56 ( history of Bihé), 2:222-23 (capture of a cannon in Haco, probably during the campaign of 1818).

49 This includes portions of the itineraries; see Stamm, "Jean-Baptiste Douville," 15 18.

${ }^{50}$ Douville, Voyage 2:324, 367-68 (Muchingi), 2:351-53, parts of 2:360 (market at Cassange), 2: 350-51 (wholly invented history of the Jaga and the Regas).

${ }^{51}$ Ibid., 2:204-06. Even so, part of the initiation proceedings is obviously wrong, but then it is precisely that part which makes it certain that Douville did not get his information directly or indirectly from Cavazzi, but either from a merchant or from the Capuchin missionary in Luanda, Ibid., 3:207-08 (the residence of the Soso chief Ambage was as far as coastal traders went inland), and 3:209 (confederation)

52 Ibid., 2:372-73, and for his supposed visit, ibid., 3:18-31.See Eva Sebestyén and Jan Vansina, "Angola's Eastern Hinterlands in the 1750s," HA 26(1999), 310, 319. 20,323,331,343, 347, and Prosper Denolf, Aan de rand der Dibese (2 vols.: Brussels, 1954), 1:691 (elsewhere, lake Mukamba).

${ }^{53}$ Douville, Voyage 2:261-62. (baobab); ibid., 2:355-58 (Cassange's rituals). 
tained aneedotes or vignettes of a sensational or exotic character, but because they are stereotypes which often occur in other documents as well. ${ }^{54}$

But not all rumors were stereotypes. Some rumors were even derived from written documents. Thus the stories told in Angola during Douville's visit about the kingdom of Mwant Yav derived for a good part from what the latter's envoys had told the governor of Angola in 1807. This is apparently the source of the name "Tandi-a-voua" given to the Lunda queen's residence far from the capital of her husband, a titillating piece of gossip of which Douville was to make the most. ${ }^{55}$ Yet another sensational rumor about the Mwant Yav that Douville heard in Luanda was the story about the Luso-African trader whom the king supposedly sacrificed and whose bones were still seen at the shrine of the god of lightning. ${ }^{56}$ The main use of hearsay of this sort to a historian is as testimony to a collective imagination, for it tells us what image Angolans of all sorts in Luanda and in district capitals held about the lands and ways of life of Africans in the far interior.

Much more useful to a scholar interested in the Ambundu way of life in 1829 are the transpositions Douville made of his own observations to different localities. These all deal with Ambundu customs transposed in foreign lands. They can therefore only be clearly recognized in localities that were not inhabited by Ambundu-speakers. Moreover, Ambundu customs mentioned in the narratives about Lubolo, Matamba, or Cassange could just as well stem from information received from persons who had been there. One can be certain of transpositions only in the narrative about the lands beyond the Kwango and those inhabited by Soso and Kongo. ${ }^{57}$ Most of them concern "customs" such as issues of inheritance or successions, rights of sale as slaves over kinsfolk, the conduct of funerals, or the election and inauguration of chiefs. ${ }^{58}$ As such descriptions actually often elaborate

54 Ibid., 2:219 (baobab), ibid., 2:357-58 (human sacrifice and cannibalism).

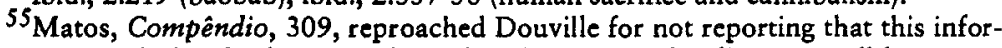
mation with details about Lunda's administration and polity was well-known to "even the most insignificant persons in the colony." Douville, Voyage 3:53-73, devoted an entire chapter to Tandi-a-voua and turned it into a sort of paradise on earth.

56 Douville, Voyage 3:77-78.

57Idem., "Aperçu," 20, declared that the Abunda (Kimbundu) language was spoken wherever he traveled, which may have suggested to him that there was little risk in transposing Ambundu customs far inland. Yet in his Voyage 3:141, 155-56, 161, 266-69, he changed his mind and he even provided very different (forged!) vocabularies for the "Bomba" languages.

${ }^{58}$ For the most obvious transpositions see Voyage 3:6-8 (residence of sons, sale of sister's sons, divorce); 3:41-42 (succession); 3:63 (granaries); 3:69-71 (justice, slavery); 3:99-100 (condemnation to slavery, deposition of chiefs); 3: 126-28 (chiefly relics and procedure for election). For descriptions resulting either from well- 
or clarify evidence given in the genuine part of the Voyage, they are a valuable complement to that evidence, with the exception of his observations about deities and their rituals, which are often fictional, excepting for many names of spirits.

Then comes inspiration drawn from publications about other parts of the world, including travel accounts by geographers or others and works of fiction. The indirect influence of Humboldt is betrayed everywhere in Douville's additions of tables and notes with fabricated astronomical, metereological, geological, zoological, and botanical data. More directly, Douville's account of his ascension of a high volcano is clearly inspired by the then-famous ascension of the Chimborazo by Humboldt, as is his fabrication of the ascension of an even higher mountain with the same name. ${ }^{59}$ Douville's claims to have personally discovered deposits of sulfur, gold, bitumen, oil, lead, copper, salt, and precious stones were also inspired, at least in part, by this illustrious example. ${ }^{60}$ Most of these deposits were well-known before his arrival, although he transposed several of them to other localities, while his descriptions betray that he did not see any of them.

Elsewhere in Douville's travels one recognizes inspiration from other travel accounts, as one encounters standard clichés such as ones dealing with deserts with the effects of lack of water or describing fights to the death between ferocious animals. It is probably not feasible to find all the literary sources that inspired Douville's narrative. One easily recognizes his favorite stereotypes, ranging from romantic stories about young maidens or the description of martial parades to sensational and licentious passages concerned with sex or religion. The depiction of the queen of Lunda, for instance, as an alluring half-clad young woman of twelve is typical, as are detailed descriptions of human sacrifice and cannibalism or of blind superstitions entertained by venal diviners that are sprinkled throughout his work. A historian of Angola will not find anything useful here, yet all of it is excellent evidence for the scholar who wants to pursue the image of Africa current at the time in France and in Great Britain, as well as for the student of what was considered sensational or shocking at the time in either country. In fact Cooley exclaimed: "He ought to have known that the superstitions of barbar-

informed travelers or transpositions see ibid., 2:191-94 (funerary customs); 2:21114 (chiefly funeral and election).

${ }^{59}$ Ibid., 2:229-33 (Zambi volcano, 3800 meters); ibid., 3:89-90 (Zambi mountain, 4600 meters)

${ }^{60}$ Ibid., 1:12-13 (sulfur, bitumen), 194-95 and 299-300 (gold); ibid., 2:254-55 (rocksalt); ibid., 3:24 (oil, bitumen); ibid., 3:46 (lead); ibid., 3:65 (precious stones); ibid., 3:87-88 (copper); ibid., 3:94 (gold). In his "Aperçu," 10, Douville claimed the discovery of copper in Encoge province, but in his Voyage he dropped both the trip and the claim. 
ians, their indecent dances and dealings with their women are not fit subjects wherewith to regale the public in an enlightened age."61

\section{VII}

And so we come to the end of the deconstruction of Douville's Voyage au Congo and the demonstration on how every part of it can be useful to historians of one kind or another. But in looking as closely as we have, we have missed the most substantial contribution to history of the whole work. Here we have an author who traveled in Angola during the last paroxysm of the slave trade and whose nearly every page of his book bears witness to practices involved in the trade, and to the callous and racist mentality it engendered. He described the great slave markets; told us how slaves are tested before they are being bought; how they were restrained; the different ethnic labels of slaves; and the differences between such groups in terms of strength, size, blackness of color, and intelligence. Thus the people of "Bie "and the "Moluas" were the most intelligent, the tallest, and the blackest. ${ }^{62}$ No need to add that they also should be the most expensive. But since this is a book of travel he was most prolix concerning the true or imagined adventures of his own caravan. These encompassed all the varied experiences and adventures of the slave-trading caravans of his time, and we may be assured that they are not sheer invention on his part, for the greatest expertise of his informants lay undoubtedly in their experience of caravans. ${ }^{63}$

Deception, intimidation, the taking of hostages, the occasional shooting of recalcitrant local inhabitants, the kidnaping of slaves, especially of women and children, the burning of their villages, the flogging to death of a thief, and even attempted insurrection by slaves-all the deeds of slave raiders are there and so are the practices of their opponents such as armed ambushes, regular affrays, fines paid for breaking all sorts of rules, the seizing of trade goods by chiefs, set in a scenery involving the business of getting the caravan fed, setting up camps, and

${ }^{61}$ See [Cooley], Article VIII, Voyage," 173; There as well (ibid., 167), we hear of "pictures of ... grossness, sensuality and debauchery" and about his fascination with and eloquence about cannibalism (ibid., 175-77). In "Article X: ma Défense," 545, Cooley spoke of things "shocking to humanity." Yet Lacordaire was apparently not shocked by any of these passages. For the general point see Philip D. Curtin, The Image of Africa (Madison, 1964).

62 Douville, Voyage 3:234; idem., Aperçu," 21, 22

${ }^{63}$ Even though it was supposedly proverbial that "three months of travel among the negroes suffice to whiten the hair and to destroy the health of a white person or a mulatto," in Douville, Voyage 3:250, as part of his appendix "Difficulties in Traveling." 
finding one's place in the layout of the great markets-all of it is to be found in Voyage. Indeed, Douville even callously boasted about all sorts of atrocities, evidently committed by others, as if they were of his own doing. His testimony about such matters is so detailed, so candid, so unintentional, and so pervasive that I know of no other text about the slave trade in central Africa that is as credible and that documents the destructive violence wrought by the slave trade as fully as Douville's account.

Indeed the text shows that Douville was so profoundly steeped in a slave-trading mentality, that it does not much matter whether he had been an illegal slave trader or not. ${ }^{64}$ It is not surprising then to find him to be an ardent proponent of the crassest possible "scientific" racism of his times, a racism particularly well-suited to-and in part developed by-slave traders, and he wanted to be thought to have contributed to its proofs. ${ }^{65}$ Thus he callously lies: "I found by means of repeated experiences that the skull of the negro contains two to four ounces less than that of the white brain." 66 Where and when exactly did this liar "repeatedly" find the skulls to do so? Racism or not though, even in the $1830 \mathrm{~s}$, callous cruelty on a Douville scale was not universally acceptable. Cooley for one was outraged and exclaimed that "[w]e find in almost every page of his volumes something vile and revolting" and went on to detail his revulsion. ${ }^{67}$ Paradoxically though, Douville's brutal mindset and his involuntary detailed exposure of the doings of the slave trade are probably the most valuable asset of his work today, an asset of which historians should make more use of than they have done hitherto.

\section{VIII}

The scholarly fallout over Douville's forgery remained modest. His book was almost immediatedly translated into Spanish by Francisco Pérez de Anaya ${ }^{68} \mathrm{~A}$ few years later it influenced da Cunha Matos who, in the survey he completed in 1836 , borrowed various statements con-

${ }^{64}$ [Cooley], "Art. X-Ma Défense", 546, charged him with having conducted a grand slaving expedition. Stamm, "Jean-Baptiste Douville", suspects that he was actually fully involved in the illegal slave trade. In any case, in several places he tells us casually how he bought and sold slaves himself.

${ }^{65}$ For a systematic exposition see his Voyage 3:234-41, and idem., "Aperçu," 21-22. On scientic racism consult Curtin, Image of Africa, 28-57, and index s.v. "racism"

${ }^{66}$ Douville, Voyage 3:24.

67 [Cooley], "Article X: Ma Défense," 545.

${ }^{68}$ Viaje al Congo y al interior del Africa equinocial verificado en los años de 1828, 29 y 30 por J.B.Douville (Madrid, 1833).

${ }^{69}$ Matos, Compêndio, was composed in 1836. 
cerning the colony of Angola proper from Douville (including the Zambi volcano) and did not always acknowledge them! ${ }^{69}$ Tito Omboni's travels to Luanda in 1835 and 1836, published in 1845, also borrowed a good deal (again including Zambi the volcano) from Douville, but again also only about parts concerning the colony proper. Even the great Mágyar borrowed at least the same volcano ("the only known volcano") either from Douville or indirectly from Omboni, thus revealing that he had never been to Libolo. ${ }^{70}$ But, Magyar apart, no author after 1840 seems to have borrowed anything any more from the Voyage. And when Lopes da Lima's book was published in 1846, it immediatedly became the standard reference, to be followed within a long decade by the travel accounts of Livingstone, Magyar, and Silva Porto.

Although I did not decorticate Douville's text page by page, I hope that I have convinced readers that it is really possible to deconstruct a text completely, and that it is truly worth doing so because historians of one sort or another can make use of all the disjecta membra. Hence, rather than just dismissing a forgery when one is found, historians of Africa should be challenged by such a find and use all of its parts for their appointed purposes, just as the central African farmer uses all the parts of the palmtree down to the last grub.

${ }^{70}$ László Magyar, Reisen in Süd-Afrika in den Jabren 1849 bis 1857, trans. János Hunfalvy, (Pest, 1859), 381-82, and endmap. 